\title{
CORDAITEAN WOOD FROM THE PENNSYLVANIAN OF KANSAS ${ }^{1}$
}

\author{
Waldo Edward Steidtmann
}

(Received for publication April 5, 1933)

Recently two samples of Pennsylvanian, silicified wood, from Kansas, were placed at the disposal of the writer. ${ }^{2}$ One of the samples is accompanied by full collection data and was found in Anderson County, Kansas, by M. K. Elias of the Kansas State Geological Survey. The other sample had a label reading "Silicified wood, Coffeyville, Potato Creek, Montgomery County, Kansas." According to the Bulletin of the Geological Survey of Kansas (Moore and Haynes, 1917), Coffeyville lies in the area where there are outcrops of the Marmaton group of the lower Pennsylvanian. Both specimens were in a collection of unstudied material in the Museum of Paleontology of the University of Michigan.

Similar material was described by Penhallow (1900) when he undertook the revision of Dawson's collection of petrified woods. In that collection there were two specimens collected by Professor Prosser in Chase County, Kansas, from the base of the Permian. One of the specimens Penhallow assigned provisionally to Dadoxylon because of its poor preservation and because it showed no definite relationship to any other genus. The other he placed in Cordaites. In both instances the description is very meager and without illustrations, so that in these respects the original publication is of little value. Through the courtesy of Dr. T. H. Clark of the Peter Redpath Museum, McGill University, the type material was loaned for comparison. The slides labeled Dadoxylon prosseri, to which the Anderson County material seems most nearly related, are useless for accurate comparison. The slides labeled Cordaites illinoisense, representing sections from three specimens, one of them originally labeled by Dawson ( 1863 ) as Dadoxylon missouricnse, differ somewhat from one another, and materially from the specimens here to be described, and will consequently be disregarded in the present paper. The Coffeyville specimen bears some resemblance to and is apparently quite closely related to Cordaites materiarum as described by Dawson (I863) and Penhallow (1900).

A number of specimens of Cordaitean wood have been described from

1 Papers from the Department of Botany and Herbarium of the University of Michigan, No. 415.

2 The writer obtained access to the material through the courtesy of Dr. C. A. Arnold of the Department of Botany and the Museum of Paleontology of the University of Michigan. 
various parts of the world. In many of these the primary structure has been absent, which has prohibited the establishment of their exact generic affinity. Because of the absence of primary structures, various criteria of secondary wood have been used in an attempt to arrive at specific determinations. The presence and absence of growth rings were used by Grand'Eury (1877) and Kraus (1864), while Dawson (1863) even founded a species on their presence. Obviously there are objections to this because of the difference of opinion as to what constitutes a growth ring and how well-defined this ring must be before it may be recognized as such. Goldring (I92I) has even placed an Oklahoma specimen, with growth rings, in the same genus and species with one of Penhallow's from Prince Edward Island, without growth rings. At any rate, there is no reference made to their presence in his description.

Attempts have been made to utilize cell measurements for identification purposes. Such measurements are used to some extent in the recognition of commercial species of modern woods, but are considered of dubious or only of regional value unless, as Desch ( 1932 ) indicates, they are taken from a large number of specimens.

The seriation and other characteristics manifested by the pits in the tracheids are used extensively as a basis for classification of secondary wood. Von Mohl (186I-I862) and Schacht (I86I-I862) have found that there may be considerable variation between the wood of a root and a stem of the same plant. Holden (1917) has pointed out a marked difference between the pitting of an Indian Pinus and the same genus from the West. Apparently, then, pitting, as a generic characteristic, must be used with some caution.

This leaves little more than the seriation and the height of the rays, the length of the ray cells, and their lateral pitting to be considered. Since the material here to be described is comparatively well preserved but consists of secondary structure only, all the above criteria for identification will be used and emphasized according to their relative value.

Carboniferous wood of the Dadoxylon type is relatively simple in structure when compared with modern gymnosperms. There may be growth rings present but they are never of the kind which exhibit broad, unmistakable summer wood. Resin ducts or resin canal systems are absent. The wood rays are usually narrow and variable in height and never fusiform. The ray cells are all of one kind and in general manifest the same type of lateral pitting. "Bars of Sanio" are generally not found separating the somewhat complex araucarian arrangement of pits. The wood may be characterized as simple and compact in nature.

Dadoxylon douglasense, sp. nov. Tracheids about $5^{8} \mu$ in radial diameter, often much less in lateral diameter; somewhat rounded, walls less than I $2 \mu$ thick. Pits in $1-2$ rows, alternating when in 2 rows, rarely appearing hexagonal when crowded, I2.5 $\mu$ in diameter, orifice lenticular, $1 / 3$ the diameter of the pit. Rays numerous, I-40 cells high, uniseriate, or biseriate in part : 
in radial view cells extending over $I / 2-7$ tracheids; the lateral walls of the ray cells and adjoining tracheids displaying $\mathrm{I}-2$ pits. Marginal ray cells often higher than ray cells and often with 3-4 pits.

Horizon, base of Douglas group, upper Pennsylvanian. Locality, near Garnett, Anderson County, Kansas. Type no. I5112, Museum of Paleontology, University of Michigan.

The specimen is a fragment of what was evidently a large trunk. It measures $20 \mathrm{~cm}$. in length and $10 \mathrm{~cm}$. in diameter and represents only a part of the radius of the stem.

A transverse thin section, held to the light, indicates a gymnospermous wood with indefinite zones which might be interpreted as growth rings. Under microscopical examination these zones are found to be mostly the result of disintegration followed by partial crushing. Nevertheless, there are zones of large cells which alternate with narrow zones of small cells. These regions are discontinuous and consequently cannot be termed as growth rings but merely as irregularities.

The tracheids are arranged in radial rows (fig. 3) and have a tendency to be rounded. In general the radial diameter of the wood cells is much the same, about $5^{8} \mu$, while the lateral diameter is variable, often not more than one-third of the radial diameter. The thickness of the tracheid walls is usually less than $12 \mu$.

The rays are mostly uniseriate but may be biseriate in part (fig. 4), brought about by the lateral division of one or a few of the ray cells. The height is variable, ranging from $I-40$ cells. The average is usually more than to cells but less than 20. These cells are about $23 \mu$ high, which is equal to the horizontal diameter. The length is quite variable, for they may extend over from I $1 / 2-7$ cells, usually $3-4$. There is considerable irregularity in the radial surface of these cells. The ends may be square, rounded, angular, or conspicuously contracted. This may be due to a partial decomposition of the original wood and pressure during petrifaction. In some instances the brown (resinous) content (fig. 2), which is so evident in many of the ray cells and in some of the tracheids, is distinctly contracted from the cell wall. The marginal ray cells are often twice as high as the regular ray cells. There are from I-5 pits in the lateral walls of each ray cell and its adjoining tracheid (fig. 2). One and two are most common ( 2 is the number which seems to predominate), whereas the marginal ray cells may have 3,4 , or 5 .

The full-bordered pits are distributed in I or 2 rows throughout the tracheids (fig. I). Only a portion of 2 tracheids was observed in which there were 3 rows of pits, but these were considerably smaller and different in appearance from the ordinary ones. Ordinarily the pits measure $121 / 2 \mu$ in diameter with the lenticular orifice $1 / 3$ of that size. Rarely are the pits crowded to such an extent as to cause them to appear hexagonal.

As mentioned previously, the material here described appears to conform in some respects to Penhallow's ( I900) description of Dadoxylon prosseri. 

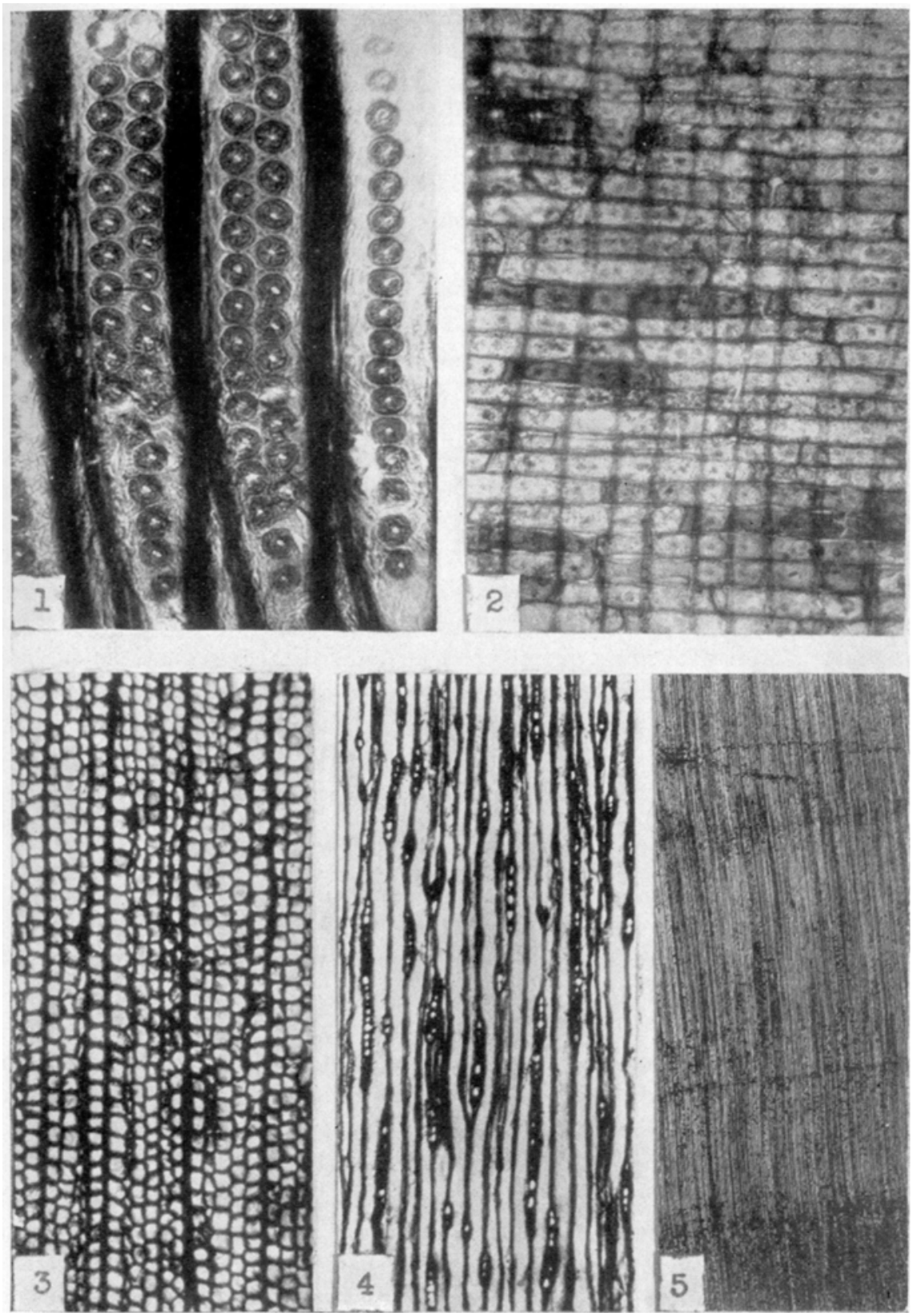

Fig. I-5. Fig. I. Radial section of Dadoxylon douglasense showing the uni- and biseriate arrangement of the pits. $\times 350$. Fig. 2. Radial section showing the lateral pitting of the ray cells and the resinous cell contents, often shrunken away from the cell wall. $\times$ i 40 . Fig. 3. Transverse section of Dadoxylon douglasense. $\times 40$. Fig. 4. Tangential section showing the seriation and the variation in the height of the ray cells. $\times$ 44. Fig. 5. Transverse section of Cordaites materiarium with growth rings. $X \equiv$. 
There are, however, several differences which distinguish the two to some extent. The height of the rays, the length of the ray cells, and their lateral pitting constitute the main differences. Penhallow does not give the height of the ray cells, but a study of his specimen would indicate that they are not as tall as those described here. The length of the ray cells of his specimen is described as extending over $2-4$ tracheids, while those in the new material have a greater range than that. Penhallow also says that the lateral walls of the ray cells have from $2-4$ pits. In the material described here, one pit is exceedingly common while four are rare and then confined mostly to the marginal ray cells. The slight difference in the seriation of the pits in the two rather swollen tracheids may be considered as an abnormality and of no important significance. There are also discrepancies in the sizes of the various types of cells, but these measurements are considered of little value because they are based on measurements obtained from a small fragment of a specimen.

Because of the differences in the height of the rays and the lateral pitting of the ray cells, and because of the fact that the material here described is in a better state of preservation, which makes it more valuable for further reference, it appears advisable to describe it as a new species. Likewise, the Douglas formation, in which Dadoxylon douglasense occurs, is separated from the lower Permian by the two upper formations of the Pennsylvanian, the Shawnee and the Wabaunsee. If the two occurred reasonably close together stratigraphically, it would be justifiable to disregard the original type of $D$. prosseri and to reestablish this species on a neotype. This course is recommended if new collections show that the type of wood here described really extends into the Permian, with enough variation to obscure the distinctions which have been pointed out.

Cordaites materiarium Dawson. The specimen from Coffeyville, Kansas, is a fragment of what was evidently a large trunk. The piece measures 15 $\mathrm{cm}$. in length, $3 \mathrm{~cm}$. in radial diameter, and $5 \frac{1}{2} \mathrm{~cm}$. in lateral diameter. All of the material is secondary wood from one radius of the stem.

Of all the material described by Penhallow (I900) and Dawson (I863), the Kansas material examined by the writer resembles Cordaites materiarium most. Several points of difference will be pointed out, but on the basis of secondary wood only, these do not justify the description of a new species.

A thin section of the material shows three distinct growth rings (fig. 5) and portions of two others. The " summer wood" is only $2-5$ cells in width but distinct. The broadest of the rings measures $6 \mathrm{r} / 2 \mathrm{~mm}$., the next $5 \mathrm{~mm}$., and the narrowest $3 \frac{1}{2} \mathrm{~mm}$. Dawson ( 1863 ), in his description of $C$. $m 2$. teriarium, refers to the " rings of growth slightly marked," while Penhallow ( 1900$)$, in his description of the same material, makes no reference to them at all. Goldring ( I92I) does not consider growth rings a characteristic of sufficient importance to separate or establish a species.

The distribution and the size of the bordered pits present another slight discrepancy. Penhallow describes the pitting as 2 - to 4 -seriate. In the material described here, one row of pits is comparatively common, three rows 
are rare, and four rows have not as yet been observed. Holden (1917), Schacht (I86I-I862), and von Mohl (I86I-I862) in their work point out that irregularities may occur in pit arrangement and it may be inadvisable to use this as a diagnostic characteristic of secondary woods of which a limited amount of material is known. The pits of the later specimen range from I2-I $5 \mu$ in diameter, and Penhallow describes those of $C$. materiarium as I $2 \mu$.

The rays of both specimens are up to 40 cells high and generally uniseriate, and the cells are similar in size. They are also of the same length, extending over 2-6 tracheids. Penhallow describes his material as having $1-5$ pits on the lateral wall of each ray cell and its adjoining tracheid, usually $\mathrm{I}-2$. In the later material the range has been found to be from I-4 with I-2 predominating.

Although there are dissimilarities between the two specimens, they are of such a nature that they may reasonably be accounted for as variations which are present in secondary wood or possibly in observations which arise from the varying preservation of the material. Because of this it appears advisable to refer it, at least for the present, to Cordaites materiarium Dn.

Probable horizon, Marmaton group, lower Pennsylvanian. Locality, Coffeyville, Potato Creek, Montgomery County, Kansas. Type no. I5I I3, Museum of Paleontology, University of Michigan.

Department of Botany,

UNIVERSITY OF MICHIGAN,

AnN ARbor, Michigan

\section{LITERATURE CITED}

Dawson, J. W. 1863. Synopsis of the flora of the Carboniferous period in Nova Scotia. Canada Nat. and Geol. 8: 43I-457.

Desch, H. E. I932. Significance of numerical values for cell dimensions. Trop. Woods 29: 14.

GoldRinc, W. 1921. Annual rings of growth in Carboniferous wood. Bot. Gaz. 72: $326-330$.

Grand'Eury, M. I877. Memoire sur la flore carbonifère du départment de la Loire et du centre de la France. Mem. Acad. Sci. Inst. France 24: 26I-272.

Holden, Ruth. 1917. On the anatomy of two Paleozoic stems from India. Annals Bot. 31: 315-326.

Knowlton, Frank H. I889. A revision of the genus Araucaryorylon of Kraus, with compiled description and a partial synonymy of the species. Proc. U. S. Mus. 12: $601-617$.

KRAUS, G. I864. Mikroskopische Untersuchung über den Bau lebender und vorweltlicher Nadelhölzer. Wurzb. naturw. Zeitschr. 5: 144-200.

Moore, Raymond C., and Winthrop P. Haynes. igr7. Oil and gas resources of Kansas. State Geol. Survey, Kansas, Bull, 3: 88.

Penhallow, D. P. Igoo. Notes on the American species of Dadoxylon, with special reference to type material in the collections of the Peter Redpath Museum. Proc. Trans. Roy. Soc. Canada II, 6: 5I-79.

Schacht, Hermann. I86I-1862. Uber den Stamm und Wurzel der Arallaria braziliensis. Bot. Zeit. 20: 409-423.

Von MoHL, Hugo. I86I-I862. Einige anatomische und physiologische Bemerkungen über das $\mathrm{Hoz}$ der Baumwurzel. Bot. Zeit. 20: 225-239; 268-287. 